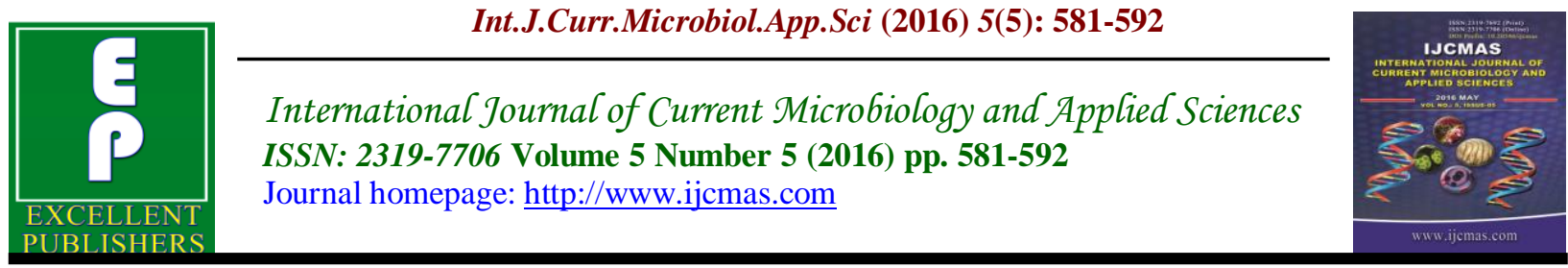

Original Research Article

http://dx.doi.org/10.20546/ijcmas.2016.505.059

\title{
Exploration of Plant-Biomass Degrading Fungi for In Vitro Mycoremediation of Toxic Synthetic Dyes
}

\author{
Raj Kumar Pandey ${ }^{1 *}$, Babita Rana ${ }^{1}$, Salil Tewari², Anwesa Sarkar, \\ Ashutosh Dubey ${ }^{4}$, Dinesh Chandra ${ }^{5}$ and Lakshmi Tewari ${ }^{1}$ \\ ${ }^{1}$ Department of Microbiology, College of Basic Sciences and Humanities, G.B. Pant University \\ of Agriculture and Technology Pantnagar, U. S. Nagar, Uttarakhand, India \\ ${ }^{2}$ Department of Genetics and Plant Breeding, College of Agriculture, G.B. Pant University of \\ Agriculture and Technology Pantnagar, U. S. Nagar, Uttarakhand, India \\ ${ }^{3}$ Department of Post Harvest Process and Food Engineering, College of Technology, G.B. Pant \\ University of Agriculture and Technology Pantnagar, U. S. Nagar, Uttarakhand, India \\ ${ }^{4}$ Department of Biochemistry, College of Basic Sciences and Humanities, G.B. Pant University \\ of Agriculture and Technology Pantnagar, U. S. Nagar, Uttarakhand, India \\ ${ }^{5}$ Department of Biological Sciences, G. B. Pant University of Agriculture and Technology \\ Pantnagar, U. S. Nagar, Uttarakhand, India \\ *Corresponding author
}

Keywords

Plant-Biomass, Mycoremediation, Toxic Synthetic Dyes, Ganoderma sps, congo red and brilliant green.

Article Info

Accepted: 18 April 2016 Available Online: 10 May 2016

\section{A B S T R A C T}

The use of extracellular enzyme systems from wood decaying fungi are now growing very fast for bioremediation of synthetic and toxic dyes from environment. In view of this, present study was undertaken for decolorization of two synthetic industrial viz. congo red and brilliant green using wood rot fungal cultures. Fifty five wood rotting fungal cultures were tested qualitatively for production of extracellular lignolytic enzymes. Selected cultures were used for testing the in vitro dye removal potential in dye containing broth. Samples were withdrawn periodically and percent decolorization was calculated. The fungal cultures removed the dye from the media either by accumulating it in mycelia (bio-sorption) or by metabolizing it to some non-coloured components. The cultures varied in their dye decolorizing potential, showing 50.21-97.37\% decolorization of brilliant green within $24 \mathrm{~d}$. All the selected cultures showed complete bio-sorption of congo red dye within one month. The efficient strains were further selected for the production of various enzymes involved in the dye decolorization and crude enzyme activities in culture supernatantes were calculated. In all the cases, maximum extracellular laccase, lignin peroxidases and $\mathrm{Mn}$ dependent peroxidase activities were observed within 15 to $18 \mathrm{~d}$ of incubation in culture supernatant. Light microscopy and phase contrast microscopy clearly revealed bio-sorption of the dye by fungal cultures in the photomicrographs. Among various cultures tested, the potential isolate showing maximum dye decolorizing/ bioabsorbing ability identified as Ganoderma sp. 


\section{Introduction}

Various synthetic and toxic dyes and pigments are used in many industries such as textile, cosmetic, printing, drug, and foodprocessing (Mohan et al., 2002). These synthetic compounds are very harmful due to their mutagenic/ carcinogenic nature and thus belong to the most dangerous pollutants. These dyes can be released into our environment as effluents from many synthesis plants and factories/ industries (Elizabeth et al., 1998). Most of these pollutants are very stable, even at extreme conditions as high temperatures, as well as to microbial attack, making them recalcitrant and tough to degrade (Pagga and Brown, 1986). The major drawback is also that sometime these compounds can be transformed to more carcinogenic compounds under anaeobic conditions (Kulkarni et al., 1985; Bumpus \& Brock 1988).

Various physicochemical methods, such as adsorption, electrocoagulation, precipitation, flocculation, ion exchange, membrane filtration, ozonation, etc. have been used for decolorization of these harmful carcinogens, however, these methods possess some limitations such as high cost, formation of hazardous by-products, and intensive energy requirements (Brown et al., 1981). On the other hand, biological processes provide a low-cost, environmentally benign, and efficient alternative for the treatment of dye wastewater (Ali et al., 2009). Currently, a lot of studies have focused on wood rot fungi that seem to be more prospective organisms because of their unique lignolytic, oxidoreductive enzyme systems. These fungi are capable of degrading many xenobiotic compounds including various types of dye such as azo, anthraquinone, reactive, and triphenylmethane dyes (Dey et al., 1994). The two methods of the bioremediation of these pollutants are biosorption, involves the entrapment of dyes in the matrix of the adsorbent (microbial biomass) without destruction of the pollutant; whereas other is biodegradation i.e. original dye structure is fragmented into smaller compounds resulting in the decolorization or many times detoxification of synthetic dyes (Singh \& Arora, 2011). Over the past few decades, numerous microorganisms have been isolated and characterized for degradation of various synthetic dyes, but there is a dearth of information regarding the complete and proper degradation and detoxification of these dyes by microbial systems despite their increased use by the textile industry. Hence, the selection of potent microbial system that have the capability for degradation and detoxification of these dyes of interest is very important from biotechnological aspect of dye effluent treatment. In view of above, present study was undertaken for the selection of potential wood rot fungal gene pool for decolorization of synthetic and toxic dyes such as congo red, and brilliant green using wood rot fungal cultures. Various wood rot fungi were isolated and checked for their dye decolorization ability on the basis of the presence of dye decolorizing unique enzymes namely laccase (Lac), lignin peroxidise (LiP) and Mn dependent peroxidase $(\mathrm{MnP})$. The laccase enzyme that was shown to be involved in decolorization reaction was quantified along with the $\mathrm{LiP}$ and $\mathrm{MnP}$.

\section{Material and Methods}

\section{Chemicals}

Veratryl alcohol, and 2,2-azinobis(3ethylbenzthiazoline-6- sulfonic acid) (ABTS), were purchaged from HiMedia Mumbai, India. The triarylmethane dye 
(brilliant green) and di-azo dye congo red used in this study were purchased from Sigma Chemical Co. (St. Louis, Mo, USA). The chemical structures and characteristics of the dyes used are depicted in Table 1. The stock solutions of each dye were prepared by membrane filtration. All other chemicals used were of analytical grade.

\section{Cultures Used}

Various lignocellulolytic fungal cultures used during present investigation, were isolated using fruiting bodies from diverse sources (decaying woods, infected wood and infected trees) collected from different locations of Uttarakhand, India. The standard cultures of plant pathogenic fungi viz. Ganoderma sp., Fusarium oxysporium, Rhizoctonia solani, Helminthosporium maydis, and Alterneria spp. were obtained from Department of Microbiology, C. B. S. H. and department of Plant Pathology, College of Agriculture, G. B. Pant University of Agriculture and Technology Pantnagar, U.S. Nagar Uttarakhand.

\section{Isolation and Conservation of Microbial Gene Pool}

All the fungal cultures were isolated and maintained on Potato Dextrose Agar (PDA) medium ( $\mathrm{gL}^{-1}$; potato peeled 200.0, dextrose $20.0 \mathrm{~g}$, and agar 15.0, $\mathrm{pH} 5.6 \pm 0.2$ ). For isolation of fungi, the small piece from the fruiting body surface sterilized using $70 \%$ ethanol, then washed with sterile distilled water and inoculated in triplicates at centre of the potato dextrose agar plates. Pure mycelial growth appeared on the plates were further purified. All the microscopic analyses were done based on LPCB (Lacto phenol cotton blue) staining.

\section{Screening for Production of Lignin Degrading Enzymes}

Screening of the cultures for overall lignin modifying activity was done using Lignin
Modifying Enzyme Basal Medium (LBM) contained $(\mathrm{g} / \mathrm{L}) \mathrm{KH}_{2} \mathrm{PO}_{4}, 1.0 ; \mathrm{C}_{4} \mathrm{H}_{12} \mathrm{~N}_{2} \mathrm{O}_{6}$, $0.5 ; \mathrm{MgSO}_{4} .7 \mathrm{H}_{2} \mathrm{O}, 0.5 ; \mathrm{CaCl}_{2} .2 \mathrm{H}_{2} \mathrm{O}, 0.01$; Yeast Extract, 0.01; $\mathrm{CuSO}_{4} .5 \mathrm{H}_{2} \mathrm{O}, 0.001$; $\mathrm{Fe}_{2}\left(\mathrm{SO}_{4}\right) 3,0.001 ; \mathrm{MnSO}_{4} . \mathrm{H}_{2} \mathrm{O}, 0.001$; Agar, 16.0 (Pointing, 1999). LBM was supplemented with $1 \mathrm{ml}$ of separately sterilized $20 \%$ glucose solution and $1 \mathrm{ml}$ of aqueous tannic acid solution to each $100 \mathrm{ml}$ of growth medium prepared. The cultures were inoculated on plates containing LBM and observed for growth and zone formation. The qualitative measure of extracellular lignin modifying activity is the presence of brown oxidation zone around the fungal colony. It is reported as the index of relative enzyme activity $\left(\mathrm{I}_{\mathrm{LIG}}\right)$. The following formula was used for calculating the ILIG index.

Screening of the cultures for extracellular laccase activity was done using assay plates contained $15 \mathrm{ml}$ of Potato Dextrose Agar (PDA) media, amended with $0.01 \%$ guaiacol (Kiiskinen et al., 2004). Active fungal culture disc was inoculated on agar medium in triplicates. The qualitative measure of extracellular laccase activity observed as presence of brick red zone of oxidized guaiacol around the fungal colony. It is reported as the index of relative enzyme activity ( $\mathrm{I}_{\mathrm{LAC}}$ ) and calculated using same formula as mentioned above.

For detection of lignin peroxidase enzyme the fungal mycelial disc inoculated on glucose malt extract salt agar medium contained glucose $2 \%(\mathrm{w} / \mathrm{v})$; malt extract $2 \%$ (w/v); $\mathrm{NaNO}_{3} 0.2 \%$ (w/v); $\mathrm{KH}_{2} \mathrm{PO}_{4}$ $0.2 \%$ (w/v); $\mathrm{KCl} 0.2 \%$ (w/v); $\mathrm{MgSO}_{4} .7 \mathrm{H}_{2} \mathrm{O}$ $0.1 \%(\mathrm{w} / \mathrm{v}) ; \mathrm{FeSO}_{4} .7 \mathrm{H}_{2} \mathrm{O} 0.002 \%(\mathrm{w} / \mathrm{v}) ; \mathrm{pH}$ 6.5 (Thiyagarajan et al., 2008). Plate was incubated at $28^{\circ} \mathrm{C}$ for 3 days and thereafter, $3 \mathrm{ml}$ of $1.7 \mathrm{mM}$ and $2.5 \mathrm{mM}$ of ABTS and hydrogen peroxide respectively were overlapped on the plate and were kept in dark at $25^{\circ} \mathrm{C}$ for 5 minutes. Appearance of 
clear bluish green zone around the fungus gave an indication of peroxidase production by the fungus. It is reported as the index of relative enzyme activity ( $\mathrm{I}_{\mathrm{PER}}$ ) and calculated using same formula as mentioned above.

\section{Dye Decolorization Study}

\section{Dye Decolorization on Agar Plate}

Dye degradation ability of selected fungal cultures was assayed in low nitrogen basal medium containing (g/L) glucose, 1.0; $\mathrm{CaCl}_{2}, \quad 1.5 ; \quad \mathrm{MgSO}_{4}, 2.0 ; \quad \mathrm{KH}_{2} \mathrm{PO}_{4}, 1.5$; $\mathrm{NH} 4 \mathrm{Cl}, 0.15$, and $1.6 \%$ agar as described by Murugesan et al., 2006. The media were supplemented with textile dyes at the concentration of $100 \mathrm{mg} / \mathrm{l}$. The above medium was poured on petri-dishes and inoculated with mycelial disc and incubated at 300C under dark. Plates were regularly monitored at every $24 \mathrm{~h}$ for growth and decolorization activities.

\section{Percent Decolourization of Dyes Using Fungal Cultures}

The cultures screened out from the above experiments were used to quantify dye decolorizing potential in vitro. The five active fungal discs were grown in the broth medium containing (g/L) glucose, 1.0; $\mathrm{CaCl}_{2}, \quad 1.5 ; \quad \mathrm{MgSO}_{4}, 2.0 ; \quad \mathrm{KH}_{2} \mathrm{PO}_{4}, \quad 1.5$; $\mathrm{NH}_{4} \mathrm{Cl}, 0.15$, supplemented with different dyes at the concentration of $100 \mathrm{mg} / \mathrm{l}$. Samples were withdrawn periodically at an interval of $72 \mathrm{~h}$ and observed for colour change by measuring optical densities, using BioMate 3S UV-Visible Spectrophotometer (Thermo Scientific). The cultures showing the bio-sorption of the dye were also checked visually and by microscopically. The percent decolorization (\%) was calculated using the following formula:

\section{Dye Decolorizing Enzyme Production from Selected Cultures}

The selected isolates were further screened for extracellular enzymes- lignin peroxidase (LiP), manganese peroxidase (MnP) and laccase (Lac) in carbon limited liquid medium which contained (g \%): glucose, $0.3 ; \quad \mathrm{KH}_{2} \mathrm{PO}_{4}, \quad 0.5 ; \quad \mathrm{NH}_{4} \mathrm{NO}_{3}, \quad 12.5 \mathrm{mM}$; $\mathrm{MgSO}_{4} .7 \mathrm{H}_{2} \mathrm{O}, 0.1$; tween 20, 0.02; veratryl alcohol, $1 \mathrm{mM}$; trace metal solution, $0.1 \%$ (Packiyam, 2013), at $\mathrm{pH}$ 5.0. For the determination of MnP activity, the basal medium was supplemented with $\mathrm{MnS04}$ $(0.05 \%)$. Growth medium $(100 \mathrm{ml})$ was taken in $500 \mathrm{ml}$ Erlenmeyer flasks and inoculated with the 5 mycellial discs. Samples were removed at regular intervals and crude enzyme collected after centrifugation at $10,000 \mathrm{rpm}$ for $10 \mathrm{~min}$, at $4^{\circ} \mathrm{C}$. This cell free supernatant was used as the source for crude enzymes. The crude enzyme from fungal culture PAF5 was prepared from optimized broth medium and subjected to the one dimensional SDSPAGE for extracellular protein banding patterns.

\section{Enzyme Assays}

Culture supernatants were used for the assay of the various lignolytic ernzymes enzymes. Lignin peroxidase (LiP) activity was assayed according to Tien and Kirk, 1988 with some modifications. Briefly it was estimated by measuring the rate of $\mathrm{H} 202$ dependent oxidation of veratryl alcohol to veratraldehyde, spectrophotometrically. The standard reaction mixture $(2.05 \mathrm{ml})$ contained $0.8 \mathrm{mM}$ veratryl alcohol in $0.1 \mathrm{M}$ citrate buffer ( $\mathrm{pH} 3.0$ ) and $1 \mathrm{ml}$ of culture supernatant. The reaction was started by the addition of $150 \mathrm{mM} \mathrm{H} 202$ and the linear increase in absorbance at $310 \mathrm{~nm}$ was monitored for one minute at $30^{\circ} \mathrm{C}$. One unit of LiP was defined as 1 umol of 
veratraldehyde formed per minute and was expressed as $\mathrm{U} / \mathrm{ml}$. MnP activity was by the method of Paszczynski et al., 1988 with some modifications, and measured by monitoring the oxidation of $\mathrm{Mn} 2+$ to $\mathrm{Mn} 3$ + . The assay solution (3.06 ml) contained $0.1 \mathrm{mM}$ guaiacol and $0.1 \mathrm{mM} \mathrm{MnS04}$ in 0.1 $M$ citrate buffer ( $\mathrm{pH}$ 5.0) with $1 \mathrm{ml}$ of culture filtrate. The reaction was started by $0.1 \mathrm{mM}$ $\mathrm{H} 202$ addition. One unit of enzyme activity was defined as the increase in absorbance at $465 \mathrm{~nm}$ per minute. The laccase activity was determined according to Niku-Paavola et al., 1990 with some modifications, by monitoring the oxidation of $500 \mu \mathrm{M}$ ABTS buffered with $50 \mathrm{mM}$ citrate buffer ( $\mathrm{pH} 4.5)$ at $436 \mathrm{~nm}$. The reaction mixture $(3 \mathrm{ml})$ contained $1 \mathrm{ml}$ of culture filtrate. One unit was defined as $1 \mu \mathrm{M}$ of ABTS oxidized per minute.

The completely decolorized broth cultures of selected isolates were also checked for the extracellular laccase enzyme activity as described above.

\section{Statistical Analysis}

Analysis of variance (ANOVA) was done with Statistical software using the program SPSS and OP Stat. All the statistical experiments were conducted in triplicates, and the results have been reported in terms of critical difference (CD).

\section{Results and Discussion}

\section{Selection of Lignolytic Fungal Cultures Based on Relative Enzyme Activity Indices}

A number of fungal strains were isolated from fruiting bodies (Figure 1) and other decaying wood samples. Out of fifty five isolates, six isolates showed overall lignin modifying activities. Out of these six isolates, five cultures showed laccase activities while lignin peroxidase activities were observed in only two isolates (Table $2)$. Thus a total of six isolates were selected on the basis of zone formation (Figure 2) and relative enzyme activity indices (Table $3)$. The values of relative enzyme activity indices varied from 1.1 to 2.0 for $\mathrm{I}_{\mathrm{LIG}}$, from 1.3 to 3.0 for $\mathrm{I}_{\mathrm{LAC}}$ and from 1.5 to 2.0 for I $_{\text {PER }}$. The maximum value for $\mathrm{I}_{\mathrm{LIG}}(2.0)$ was shown by the fungal isolate PAF7, whereas maximum relative laccase activity indices (3.0) were found for the isolate PAF5. Only two fungal cultures PAF5 (2.0) and Ganoderma sp. (1.6) were found positive for peroxidase relative activity indices (Table $3)$.

\section{Dye Decolorization Study}

Several wood rotting fungi have been reported to possess lignin degrading (ligninolytic) enzymes and hence play an important role in the degradation of Lignocellulosic waste in the ecosystems. These lignin-degrading enzymes have been reported to be not only directly involved in the degradation of lignin in their natural lignocellulosic substrates but also in the degradation of various synthetic xenobiotic compounds, including dyes (Okino et al., 2000). Therefore, to confirm the fungal dye decolourizing capacity, two synthetic dyes were incubated with the five selected fungal isolates for $21 \mathrm{~d}$ on dye containing agar and liquid medium at $28^{\circ} \mathrm{C}$ during the present study. Out of the two dyes tested, all the fungal cultures were poor to grow very efficiently on both dyes containing agar media (figure 3), thereby showing more resistance towards both dyes. The similar agar plate screening method for determining dye decolourizing potential of wood rot fungi Ganoderma sp. has also been performed in previous study (Arulmani et al., 2005). Broth cultures were found better 
as compared to solid cultures for decolourization studies because in all the cases although fungal growth was observed in the presence of dyes but decolourization began with the formation of very less intense or negligible decolorized zones. During the liquid cultivation experiments, the batch cultures turned from an initial deep coloration to a lighter colour, eventually becoming colourless in most of the cases, indicating either the dye decolorization or dye adsorption into the fungal mycelia (Figure 4). The extent of dye decolourization by broth cultures was monitored spectrophotometrically. The spectrophotometric quantification results revealed clearly the high decolourization potential of fungal cultures towards brilliant green, and congo red dyes (Table 4).

The degree of maximum percent decolourization of brilliant green dye using various fungal isolates varied from 50.21 (PAF7) to 97.37 (PAF5). Congo red dye was removed efficiently by all selected cultures and percent decolourization of the broth varied from 94.00 (PAF7) to 98.58 (PAF5) within $15 \mathrm{~d}$ of incubation. Previously only $40 \%$ decolourization of anthraquinone dye, Remazol Brilliant Blue R (RBBR) by Ganoderma sp. was reported which could be increased up to $92.4 \%$ upon addition of HBT as redox mediator (Murugesan et al., 2006).

However, contrary to previous findings, we could get much higher decolourization rate for the two dyes congo red, and brilliant green by the fungal isolates used. Thus from the above data, the culture PAF5, showing maximum percent decolourization of brilliant green and congo red was selected as a potential wood rotting fungal culture for further experiments.

Thus on the basis of relative enzyme activity indices and dye decolourization potential, the four fungal isolates viz. PSB1, PAF5,
PAF7 and Ganoderma sp., were selected for enzyme production and further studies.

\section{Enzyme Assay}

The selected cultures were grown in enzyme production liquid medium amended with varatryl alcohol as inducer. Only extracellular laccase enzyme was synthesized maximally with peak laccase activity of $164.63 \mathrm{U} \mathrm{ml}^{-1}$ by fungal isolate PAF5 on 18th $d$ of incubation (Figure 5). The LiP and MnP were synthesized in very less amount with peak lignin peroxidase activity of $0.34 \mathrm{U} \mathrm{ml}^{-1}$, was observed with fungal isolate PSB1 within $21 \mathrm{~d}$ of incubation; and manganese dependent peroxidase activity of $0.0022 \mathrm{U} \mathrm{ml}^{-1}$ also with the fungal culture PAF5 on the $21 \mathrm{~d}$ of incubation (data not shown). In this way, the fungal cultures were able to secrete all the three extracellular oxidative and reductive enzymes. The cultures showed maximum ability for synthesizing laccase enzyme while all the cultures had very low LiP and MnP biosynthetic abilities. The enzymatic decolourization by potential fungal isolate PAF5 was also confirmed by checking laccase enzyme activities in completely decolorized (40 d old) fungal culture filtrates grown in presence of Congo red, and brilliant green dyes. The enzyme activity was determined in completely decolourized culture filtrates because due to the intense colour of the dye in medium one could not calculate the activity in dye containing broth. The very low laccase activity in Congo red containing culture filtrate of PAF5 $(1 \mathrm{U} / \mathrm{ml})$ may be partially correlated with the maximum bio-sorption of the dye by fungal mycelium and partially due to ageing of the culture that might have had lead to the degradation of the enzyme protein. Maximum laccase activity of 28.9 $\mathrm{U} / \mathrm{ml}$ was observed in completely decolourized culture filtrates (40 d old) of brilliant green dye (figure $6, a$ ). 
Table.1 The Structural Formulae, Industrial uses and hazardous effects of the synthetic Dyes decolourized during Present Study*

\begin{tabular}{|l|l|l|l|}
\hline S.No. & Dye & Chemical Structure & $\begin{array}{l}\text { Uses and Hazards } \\
\text { genotoxic and carcinogenic } \\
\text { properties } \\
\text { induces vomiting when swallowed } \\
\text { and is toxic when ingested }\end{array}$ \\
\hline 3 & $\begin{array}{l}\text { Brilliant } \\
\text { Green }\end{array}$ & Congo red &
\end{tabular}

*Source: Wikipedia Free Encyclopedia

Table.2 Diversification of Fungal Isolates On the Basis of Qualitative Enzyme Assay

\begin{tabular}{|c|c|c|c|c|c|}
\hline S.No. & $\begin{array}{c}\text { Enzyme } \\
\text { Activity }\end{array}$ & $\begin{array}{c}\text { Total } \\
\text { Isolates }\end{array}$ & $\begin{array}{c}\text { Isolates } \\
\text { showing } \\
\text { positive enzyme } \\
\text { activity }\end{array}$ & $\begin{array}{c}\text { Isolates do not } \\
\text { showing } \\
\text { enzyme activity }\end{array}$ & Selected Isolates \\
\hline 1 & $\begin{array}{c}\text { Overall lignin } \\
\text { modifying } \\
\text { activity }\end{array}$ & 55 & 6 & 49 & $\begin{array}{c}\text { PSB1, PAF1, PAF3, } \\
\text { PAF5, PAF7, Ganoderma } \\
\text { sp. }\end{array}$ \\
\hline 2 & $\begin{array}{c}\text { Laccase } \\
\text { activity }\end{array}$ & 55 & 5 & 50 & $\begin{array}{c}\text { PSB1, PAF3, PAF5, } \\
\text { PAF7, Ganoderma sp. }\end{array}$ \\
\hline 3 & $\begin{array}{c}\text { Overall } \\
\text { peroxidase } \\
\text { activity }\end{array}$ & 55 & 2 & 53 & Ganoderma sp., PAF5 \\
\hline
\end{tabular}

Table.3 Relative Overall Lignin Modifying Activity Indices of Selected Fungal Cultures

\begin{tabular}{|c|c|c|c|c|}
\hline S.N. & Culture & Relative index $\left(\mathbf{I}_{\text {LIG }}\right)$ & $\begin{array}{c}\text { Relative index } \\
\left(\mathbf{I}_{\text {LAC }}\right)\end{array}$ & $\begin{array}{c}\text { Relative index } \\
\left(\mathbf{I}_{\text {PER }}\right)\end{array}$ \\
\hline 1 & PSB1 & 1.1 & 2.3 & - \\
\hline 2 & PAF1 & 1.2 & - & - \\
\hline 3 & PAF3 & 1.4 & 1.3 & 2.0 \\
\hline 4 & PAF5 & 1.8 & 3.0 & - \\
\hline 5 & PAF7 & 2.0 & 2.3 & 1.5 \\
\hline 6 & Ganoderma sp. & 1.4 & 2.4 & $\begin{array}{l}\text { SEm } \pm 0.01 \\
\text { CD at 5\% }=0.15\end{array}$ \\
\hline
\end{tabular}


Table.4 Percent Decolorization of Malachite Green and congo red using selected Lignolytic Fungal Cultures

\begin{tabular}{|c|c|c|c|}
\hline \multirow{2}{*}{ S.No. } & \multirow{2}{*}{ Fungal Culture } & \multicolumn{2}{|c|}{ Percent Decolourization (\%) } \\
\cline { 3 - 4 } & & Brilliant Green & Congo Red \\
\hline 1 & PSB1 & 92.66 & 95.85 \\
\hline 2 & PAF3 & 96.35 & 96.84 \\
\hline 3 & PAF5 & $\mathbf{9 7 . 3 7}$ & $\mathbf{9 8 . 5 8}$ \\
\hline 4 & PAF7 & 50.21 & 94.00 \\
\hline 5 & Ganoderma sp. & 96.59 & 96.89 \\
\hline & \multicolumn{2}{|l|}{$\begin{array}{l}\text { SEm } \pm 0.155 \\
\text { CD at } 5 \%=0.505\end{array}$} \\
& \multicolumn{2}{l}{ SEm \pm 0.142} \\
\end{tabular}

Fig.5 Fruiting bodies of few wood rot fungi selected for the study PAF3 (a), PAF5 (b), and PSB1 (c).

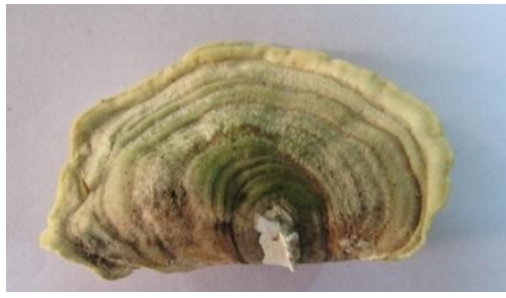

A

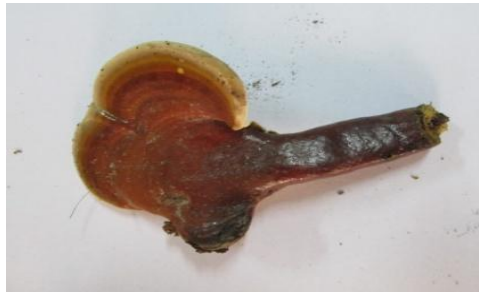

B

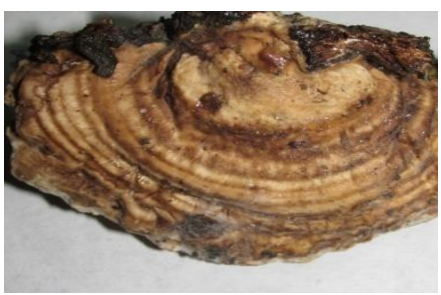

$\mathrm{C}$

Fig.6 Zone formation around the colony by selected isolate for various enzyme activities viz., overall lignin modifying activity by (a), laccase activity (b) and lignin peroxidase acitivity (c) using fungal culture PAF5.

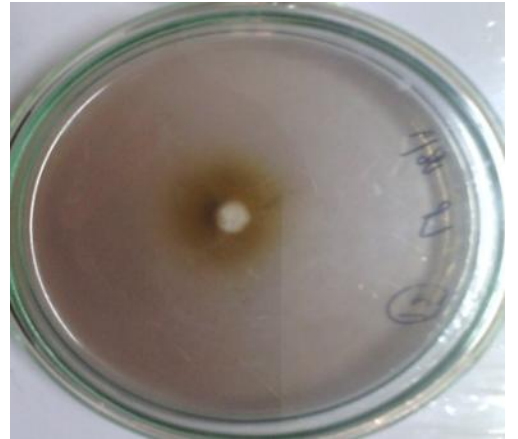

A

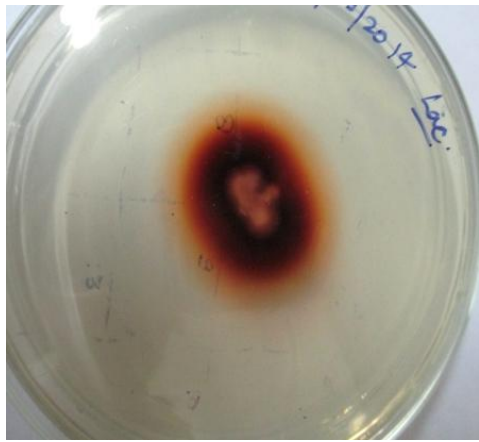

B

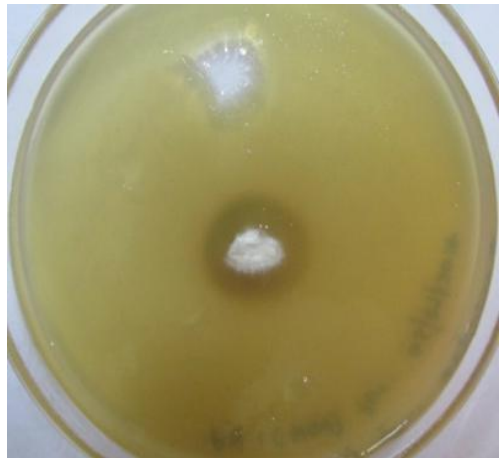

C 
Fig.7 Qualitative detection of the dye decolorizing potential of the fungal isolates on agar plate. Brilliant green decolorization by Ganoderma sp. (a), and congo red decolorization by

PAF5 (b).

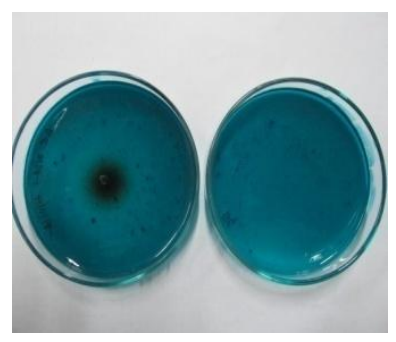

A

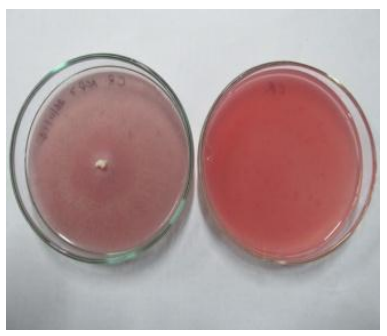

B

Fig.8 Dye decolorization and bio-absorption by fungal cultures. Bio-absorption of congo red by PAF5 (a), decolorization of brilliant green by

Ganoderma sp (b), decolorization of brilliant green by PAF5 (c), phase contrast microscopic view of the fungal mycelia showing the attachment/ accumulation of the dye congo red by fungal culture PAF5 (d).

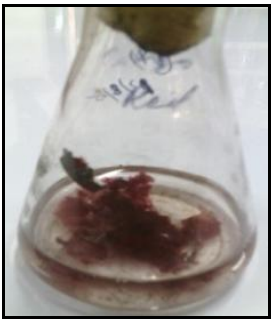

A

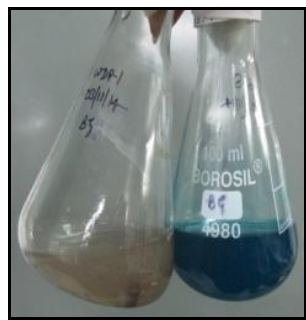

B

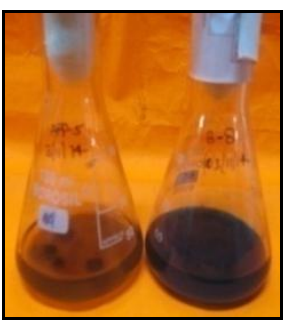

C

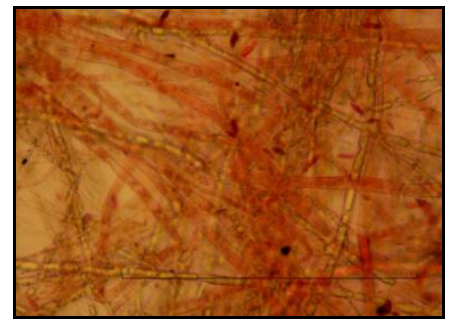

D

Fig.9 Laccase production during growth of fungi. The fungal cultures were grown in standard conditions in defined medium ( $\mathrm{pH}$ 6) at $30^{\circ} \mathrm{C}$. Maximum enzyme activity was observed in culture filtrate of fungal culture PAF5.

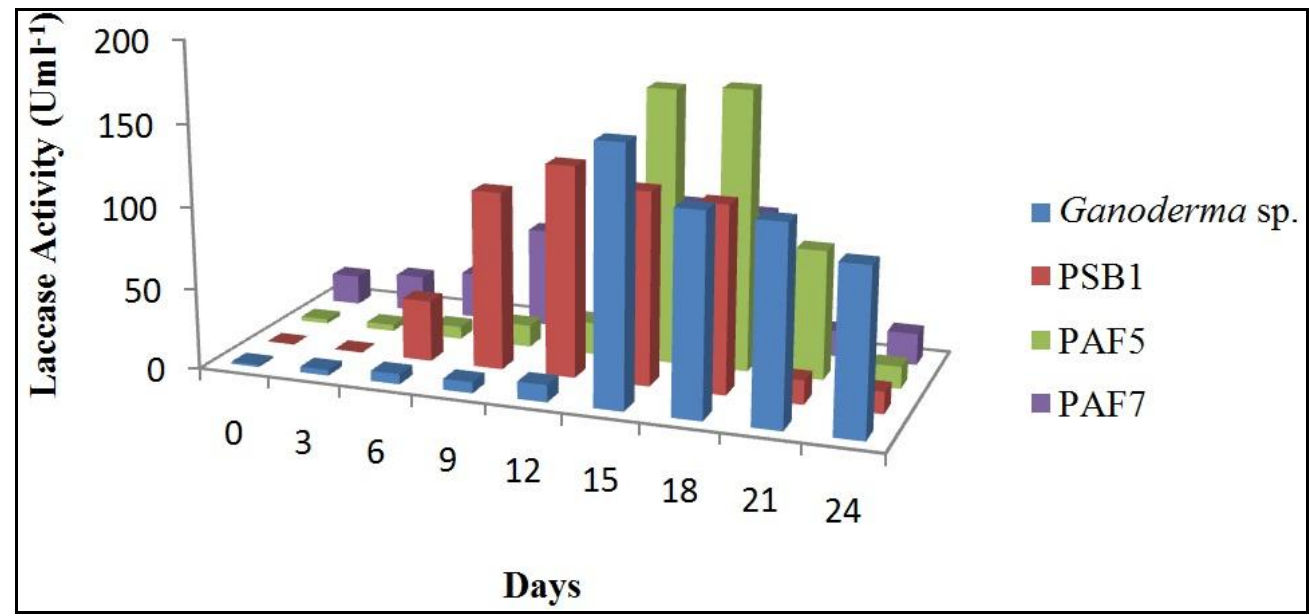


Fig.10 Laccase enzyme activity in brilliant green containing decolourized broth by fungal culture PAF5 (a), colour produced after addition of $500 \mu \mathrm{M}$ ABTS within 0 min. (a1) within $1 \mathrm{~min}$. (a2) and within 2 min. (a3); Extracellular protein profiling of potential culture PAF5 (b1). $\mathrm{M}$ is broad range (10-230 kDa) pre-stained protein ladder (New England BioLabs).

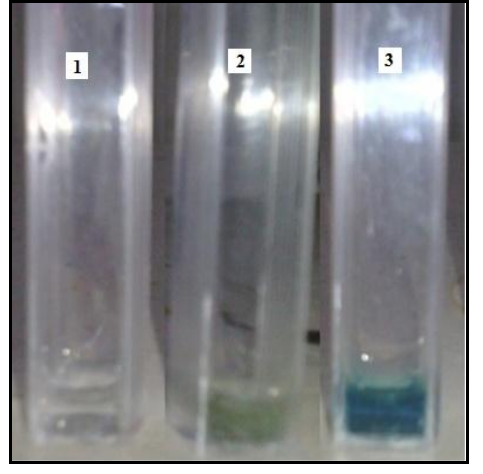

A

This induction of enzymes may be correlated with their involvement in dye decolourization process. Significant roles of Lignin peroxidase, Mn-dependent peroxidase, and laccase in dye degradation by wood rotting fungi have been well documented (McMullan et al., 2001). Further, among these three enzymes, direct involvement of laccase in decolourization of synthetic dyes has also demonstrated by previous workers (Novotny et al., 2004).

Thus, our results are in agreement with the previous findings that have also revealed the vital role shown by laccase enzyme in bioremediation of synthetic toxic dyes. In SDS-PAGE, Variable banding pattern of extracellular proteins were observed for PAF5 using laccase production medium. The molecular weight of extracellular proteins varied from $10 \mathrm{kDa}$ to $80 \mathrm{kDa}$ and a total of five Coomassie Brilliant Blue $\mathrm{G}$ (Hi Media) stained bands were observed (Figure $6, b)$. The results showed the production of laccase and other related enzymes, as the same size range is also reported for laccase in various studies (Edens et al., 1999; Imran et al., 2012).

The most potential fungal isolate, PAF5, was selected for further studies based on its

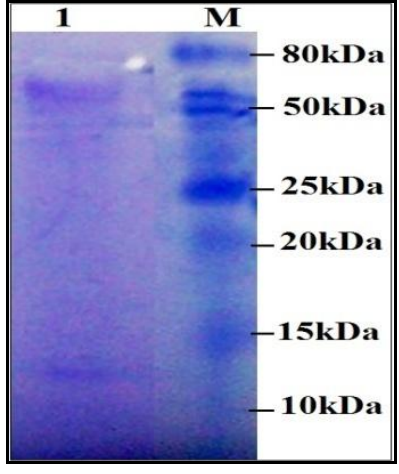

B

maximum ability to synthesize laccase enzyme and dye decolourizing ability.

\section{Identification of Potent Isolate}

The most potential isolate, PAF5 was selected for further study based on its maximum zone of laccase enzyme production, maximum enzyme production in broth media, and maximum ability to decolorize the industrial dyes. The culture was identified as Ganoderma sp. based on phenotypic characteristics and the molecular characterization of the isolate is under process.

It may be concluded from the present investigation that mycoremediation employing wood rotting fungi has a vast potential for decolourization or removal of toxic carcinogenic synthetic dyes from the industrial effluents. Moreover, biological removal of dye from industrial effluents may be more economic and ecofriendly approach. It is also apparent from the study that most of the lignolytic fungi are having very high biosorption potential towards the synthetic dyes such as congo red, indicating its efficiency for utilization in effluent treatment processes in future. 


\section{References}

Ali, H., Ahmad, W., Haq, T. 2009. Decolorization and degradation of malachite green by Aspergillus flavus and Alternaria solani, African $J$. Biotechnol., 8: 1574-1576.

Arulmani, M., Murugesan, K., Arumugam, P., Dhandapani, R., Kalaichelvan P.T. 2005. Decolorization of basic dyes methyl violet and emerald green by Pleurotus sajorcaju and its effluent decolorization activity, Indian J. Appl. Microbiol., 1: 47-52.

Brown, D.H., Hitz, H.R., Schafer, L. 1981. The assessment of the possible inhibitory effect of dyestuffs on aerobic wastewater bacteria. Experience with a screening test. Chemosphere, 10:245-261.

Bumpus, J.A., Brock, B.J. 1988. Biodegradation of crystal violet by white rot fungus Phanerochaete chrysosporium, Appl. Environ. Microbiol., 54: 1143-1150.

Dey, S., Maiti, T.K., Bhattacharyya, B.C. 1994. Production of some extracellular enzymes by a lignin peroxidase-producing brown rot fungus, Pleurotus ostreiformis, and its comparative abilities for lignin degradation and dye decolorization, Appl. Environ. Microbiol., 60: 42164218.

Edens, W.A., Goins, T.Q., Dooley, D., Henson, J.M. 1999. Purification and characterization of a secreted laccase of Gaeumannomyces gramminis var. tritici. Appl. Environ. Microbiol., 65: 3071-3074.

Elizabeth, R., Michael A.P., Rafael, V-D. 1998. Industrial Dye Decolorization by Laccases from Ligninolytic Fungi, Curr. Microbiol., 38: 27-32.

Imran, M., Asad, M.J., Hadri, S.H., Mehmood, M. 2012. Production and industrial applications of laccase enzyme. J. Cell and Mol. Biol., 10(1): $1-11$.

Kiiskinen, L.L., Ratto, M., Kruus, K. 2004. Screening for novel laccase-producing microbes, J. Appl. Microbiol., 97: 640-646.

Kulkarni S.V., Blackwell, C.D., Blackard, A.L., Stackhocese, C.W., Alexander, M.W. 1985. Textile dyes and dyeing equipment, classifi- cation, properties and environmental aspects. U.S. Environmental Protection Agency, Research Triangle Park, NC. EPA600/2-85/ 010.

McMullan, G., Meehan, C., Conneely, A., Kirby, N., Robinson, T., Nigam, P., Banat, I.M., Marchant, R., Smyth, W.F. 2001. Microbial decolourization and degradation of textile dyes, Appl. Microbiol. Biotechnol., 56: 81-87.

Mohan, S.V., Rao, N.C., Srinivas, S., Prasad, K.K., Karthikeyan, J. 2002. Treatment of simulated Reactive Yellow 22 (azo) dye effluents using Spirogyra species, Waste Management, 22: 575-582.

Murugesan, K., Nam, I., Kim, Y., Chang, Y. 2006. Decolourization of reactive dyes by a thermostable laccase produced by Ganoderma lucidum in solid state culture, Enzyme and Microbial Technol., 40: 1662-1672.

Niku-Paavola, M.L., Karhunen, E., Kantelinen, A., Viikari, L., Lundell, T., Hatakka, A. 1990. The effect of culture conditions on the production of lignin modifying enzymes by the white-rot fungus Phlebia radiate, $J$. Biotechnol., 13: 211-221.

Novotny, C., Svobodova, K., Erbanova, P., Cajthaml, T., Kasinath, A., Lang, E., Sasek, V. 2004. Lignolytic fungi in bioremediation: extracellular enzyme production and degradation rate, Soil biol. Biochem., 36: 1545-1551. 
Okino, L.K., Machado, K.M.G., Fabris, C., Bononi, V.L.R. 2000. Ligninolytic activity of tropical rainforest basidiomycetes. World J. Microbiol. Biotechnol., 16: 889-893.

Packiyam, E.J.E. 2013. Production, Purification, and Partial Characterization of laccase produced from Pleurotus florida and its potential applications. Thesis. Doctor of Phylosophy. Bharathiar University Coimbatore.

Pagga, U., Brown, D.H. 1986. The degradation of dyestuffs, part II: Behaviour of the dyestuffs in aerobic biodegradation test, Chemosphere, 15: 479-491.

Paszczynski, A., Crawford, R.L., Huynh, V. 1988. Manganese peroxidase of Phanerochaete chrysosporium: purification, Methods in Enzymol., 161: 264-270.

Pointing, S.B. 1999. Qualitative methods for the determination of ligno-cellulolytic enzyme production by tropical fungi, Fungal Diversity, 2: 17-33.

Singh, K., Arora, S. 2011. Removal of synthetic textile dyes from wastewaters: a critical review on present treatment technologies, Critical Rev. Environ. Sci. Technol., 41: 807-878.

Thiyagarajan, A., Saravanakumar, K., Kaviyarasan, V. 2008. Optimization of extracellular peroxidsae production from Coprinus sp., Indian J. Sci. Technol., 1: 1-5.

Tien, M., Kirk, K. 1988. Lignin peroxidase of Phanerochaete chrysosporium, Methods in Enzymol., 161: 238-249.

\section{How to cite this article:}

Raj Kumar Pandey, Babita Rana, Salil Tewari, Anwesa Sarkar, Ashutosh Dubey, Dinesh Chandra and Lakshmi Tewari. 2016. Exploration of Plant-Biomass Degrading Fungi for In Vitro Mycoremediation of Toxic Synthetic Dyes. Int.J.Curr.Microbiol.App.Sci. 5(5): 581592. doi: http://dx.doi.org/10.20546/ijcmas.2016.505.059 